\title{
EXPLORING DOMAINS AND ELEMENTS FOR BEHAVIOURAL COMPETENCY AND EMPLOYABILITY SKILLS
}

\author{
Abd Samad, N. ${ }^{1}$, Wan Ahmad, W.M.R. ${ }^{2}$, Sern, L.C. ${ }^{3}$, Harun, H. ${ }^{4}$, \\ Awang, H. ${ }^{5}$ \& Mohd Noor, S.N.F. ${ }^{6}$ \\ ${ }^{1,2,3,4,5,6}$ Faculty of Technical and Vocational Education, Universiti Tun Hussein Onn Malaysia, \\ 86400 Batu Pahat, Johor Darul Takzim
}

Correspondence author email: noorazman@uthm.edu.my

Received February 20 ${ }^{\text {th }}$, 2017; Accepted June $7^{\text {th }}, 2017$

\begin{abstract}
Technical Vocational Education Training (TVET) system is crucial in producing skilled workers who can command high incomes, which in turn will help Malaysia achieve the developed nation status by the year 2020. There is a mismatch between the graduates produced by the Public Skills Training Institutes in Malaysia and the competent workforce required by the industry. Therefore, this study aims to explore the domains and elements that can help automotive industry trainees acquire behavioural competence and employability skills. The Delphi technique is used to explore the domains and elements that contribute towards the integration programme for the Public Skills Training Institutes (PTSIs) and Private Training Centres (PTCS) involved in churning out automotive industry trainees. Analysis of interview data from the two rounds of the Delphi study indicates that 12 domains contribute to shaping behavioural competence and employability skills, namely governance; framework of qualifications; standard of competence; supplier of skill standards; delivery; industrial relations; experience of industrial work; twinning programmes; community service programmes; curriculum-based industrial visits; and educational entrepreneurship.
\end{abstract}

Keywords: Employability skills, competency, Delphi technique, private training centre

DOI: https://10.30880/jtet.2018.10.01.007

Vol. 10, No.1 $\quad$ June 2018| ISSN 2229-8932 Journal of Technical Education and Training (JTET) | 82 


\section{INTRODUCTION}

Competence acquired through institutional learning is inadequate in preparing graduates to fulfil the skilled labour needs of the industry (Ahmad Nordin, 2009). Based on the study of the International Labor Organization (ILO), Othman (2003) and Loose et. al (2008) lamented that low levels of competence and skills are also due to poor-quality internship or practical training system implemented in the PTSI; these practical training programmes are quite far behind the real working environment of the industry. To overcome the problems of training systems implemented, trainees should be provided with the workplace environment that offers real experiences of job training. The TVET training system is the foundation for producing skilled workers who are sought after by the employers in the labour market (Sulaiman et al, 2008). The training system today should involve strategic collaboration between training institutions and industrial establishments; there is a need for the two parties to forge close cooperation to strengthen and improve the skills of trainers in the industry (Tomiran, 2008; Rashidi, 2008; Sulaiman, 2010).

The existing training system is not in line with the needs of the industry due to the lack of collaboration between the training institutions and the industry (Department of Skills Development, 2012). PTSIs should collaborate with the industry in designing the training system and programmes with the aim of producing skilled workers in technical fields; this exercise also serves to implement the scheme of introducing broader skills such as applying generic skills in the job for coaching purposes (Callan, 2002; Jab, 2007; and Esa, 2006). The current training system of institutions should be reviewed; the existing curriculum should take into account workable skills so that training institutions can produce workers who not only possess strong basic skills but have good knowledge of social values (Ismail et al 2009; Buntat, 2004; Ministry of Higher Education, 2006a). In addition, the teaching staff should be exposed to the changing requirements of the industry so that trainers or coaches produced are in accordance with the standards of the labour market (Pillai \& Yusof, 2005; Emat, 2005). According to Ahmad (2012), the training system is considered effective when it can produce high-skilled graduates who meet the criteria of the industry. This can be achieved by focusing on a two-pronged strategy: learning based on industrial experience and studying of theories at Public Training Skills Institutes (PTSIs). For example, the existing curriculum of the National Dual Training System (NDTS) meets the needs of particular industries but the problem lies in the difficulty of obtaining industry support to make the system work (Pang, 2008b; Fong, 2005; Wan Ahmad, 2004; and Othman, 2003). Figure 1 shows the Conceptual Framework of Exploration Study on the Formation of Domains and Elements of Behavioural Competency and Employability Skills for Automotive Industry Trainees. 


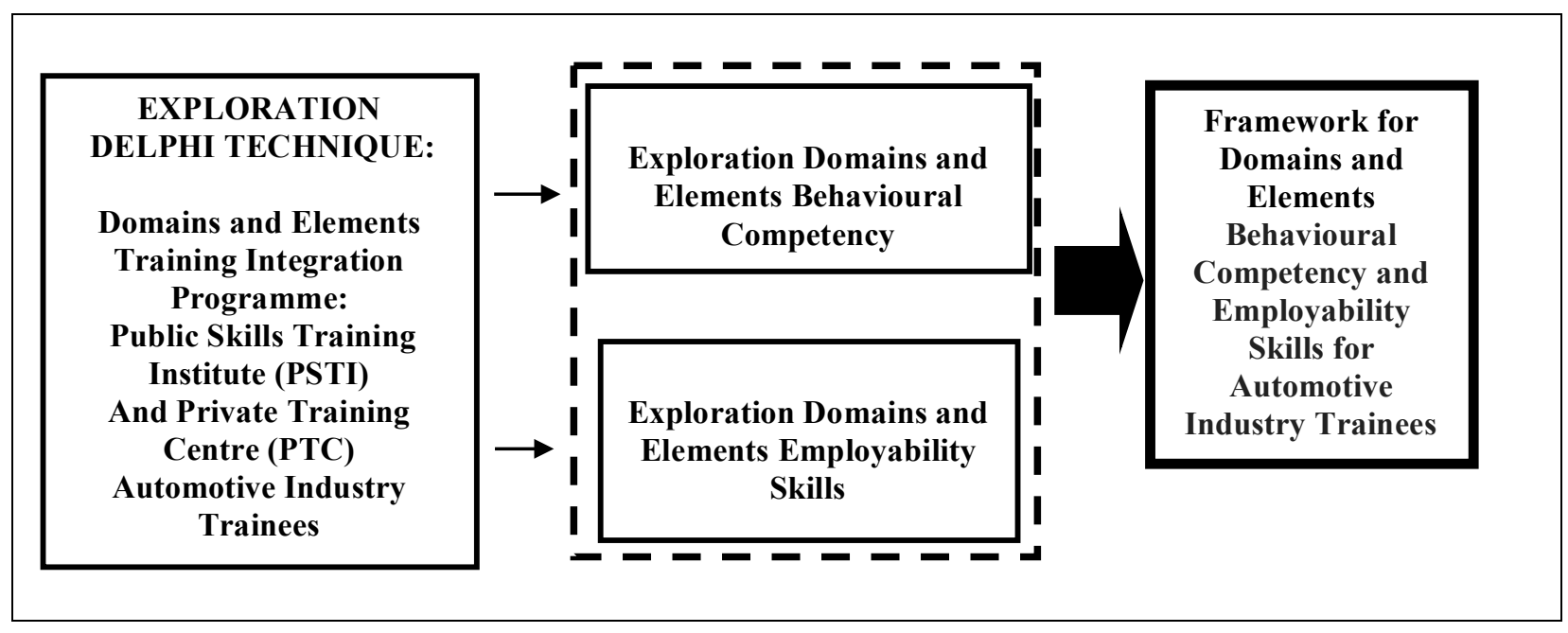

\section{Figure 1: Conceptual Framework of Exploration Study on the Formation Domains and Elements of Behavioural Competency and Employability Skills for Automotive Industry Trainees}

\section{PROBLEM STATEMENT}

As the country aspires to achieve the developed status, Malaysia has implemented a strategy of rapid industrialisation and modernisation in order to become an industrialised country by the year 2020 (Emat, 2005). As the Malaysian economy strengthens gradually within the setting of the world economic system, Malaysia is experiencing a second wave of the GTP and ETP in the midst of implementing the 10th Malaysia Plan. However, the PTSI training system has yet to reach a satisfactory level in producing workers who are competent and possess workable skills, due mainly to the lack of collaboration between the training institutions and the industry. Rahim (2009) states that collaboration between the institutions and the industry in terms of industrial training should be taken seriously. This partnership between the public training institutions and the private sector is not running smoothly; some firms of the industry are not willing to provide the necessary cooperation. Few coaches are available to provide a scope of work in accordance with the learning level, and there are complaints that trainees are not given the appropriate scope of work (Md Ali, Yusof \& Matzin, 2008; ILO, 2003). The indústrial training should provide an opportunity for trainees to be exposed to the real-life work experiences, but this objective cannot be achieved if firms of the industry are not serious in playing their roles. Based on the studies of Meseran et al. 2007 and Ismail, 2007, the industrial training or training placement is important because it can improve the behavioural and competency skills of trainees.

The level of technical competency and behavioural skills of graduates produced by PTSIs is still low compared with that of the Private Training Centres (PTCs) (Othman, 2003; Pang, 2008). The employers of the automotive industry today require employees that possess a high level of competence and skills due to rapid changes in the automotive industry. On the other hand, the quality of employees has not caught up with the standards required by the industry; this mismatch occurs because the training system, curriculum and training infrastructure of PTSIs have not been upgraded in accordance with the changes in the automotive industry. This study also found that there is no uniform system of training between the coaches of PTSIs and

Vol. 10, No.1 $\quad$ June 2018| ISSN 2229-8932 Journal of Technical Education and Training (JTET) | 84 
the industry; workers produced by the institutions are less competitive, non-skilled, and not sensitive to changes in the workplace required in the automotive industry. The PTSI training system is still lagging behind and has failed to produce a competent workforce equipped with workable skills required by the industry. If the problem cannot be solved, the employers of the automotive industry would find it difficult to recruit competent workers. Therefore, this study aims to explore the domains and elements that contribute to the formation of behavioural competence and workable skills for the automotive industry.

\section{METHODOLOGY}

This research adopts a four-round Delphi study to explore the domains and elements that contribute to the formation of behavioural competencies and skills required by the automotive industry. In the first round of the Delphi technique, the researcher used the semi-structured interview protocol involving a panel of 11 expert $(n=11)$. For the second round, the researcher used structured protocols. After the third and fourth rounds, the researcher developed a questionnaire based on the agreement from the panel of experts. Analysis of the data is presented in the form of descriptive statistics interquartile range or range, percentage, mean and median of the approval decision of the panel of experts involved. Descriptive statistics are used to describe the variable in a phenomenon and it should be explained logically by using certain methods (Balnaves \& Caputi, 2001; Chua, 2006; Vogt 2007). One way is to use the Central of Tendency Test (CTT). According to Minghat (2012) and Marican (2005), descriptive statistics interquartile range, mean, median and percentages can be used to get a view of the panel of experts on elements of the questionnaire. The mean score describes the order of priority elements. The median score functions in identifying statements that are required to establish a questionnaire on each round Delphi study engineering. This is to illustrate the level of agreement of the panel of experts on the elements of the CTT questionnaire. Table 1 shows the CTT score level of agreement (Peck and Dover, 2012).

Table 1: Central of Tendency Test (CTT) score for level of consensus (Peck and Devor, 2012)

\begin{tabular}{cll}
\hline Central of Tendency Test score & Level of consensus \\
\hline $0-1$ & High \\
$1.01-1.99$ & Moderate \\
$\geq 2$ & Low \\
\hline
\end{tabular}

\section{ANALYSIS AND RESULT}

Based on the overall analysis of the interview data domain technique in the first round utilising Delphi, the study has produced nineteen domains, namely (1) governance; (2) policies training; (3) finance and incentives; (4) qualifications framework; (5) provider of skill standards; (6) certification; (7) industrial tours based curriculum; (8) delivery; (9) infrastructure; (10) evaluation; (11) twinning programme; (12) experience of industrial work; (13) training workplace; (14) community service programme; (15) industrial relations; (16) standards of competence; (17) use of technology; (18) quality assurance (QA); and (19) education for 
entrepreneurship. All the findings of these domains were obtained during the process of interviews conducted with expert panel $(n=11)$. Table 1.2 shows the domain exploratory analysis techniques of the first round Delphi study $(\mathrm{n}=11)$.

\subsection{Exploration and element data domain interviews (second round)}

Based on the analysis of domains and elements of the second round, the panel of experts unanimously agreed that there are only twelve domains that require integration between the PTSI training programme and that of the PTC, namely (1) governance; (2) framework of qualifications; (3) standard of competence; (4) supplier of skill standards; (5) delivery; (6); (7) industrial relations; (8) experience of industrial work; (9) twinning programme; (10) community service programme; (11) curriculum-based industrial visits; and (12) educational entrepreneurship. All findings of the domains identified were obtained during the process of structured interviews conducted. Table 1.3 shows the domain analysis and technical elements of the second round of the Delphi study $(\mathrm{n}=11)$.

\subsection{Domain analysis and element (third round)}

The researchers built the domains and elements based on the results from the first and second rounds of the Delphi survey, which are the agreed decisions of the panel experts $(n=11)$. The researchers also used the taxonomy to build an element based on three levels, namely (1) receive and appreciate the base-level; (2) the level of complex-use and produce; (3) high-level high thinking. The number of elements on hard floors (high) and simple elements (basic) is less than the average level of elements (complex). In the domain analysis and elements of the third round, the panel experts agreed that twelve domains require integration between the PTSI training programme and that of PTC, namely (1) governance; (2) framework of qualifications; (3) standard of competence; (4) supplier of skill standards; (5) delivery; (6); assessment; (7) industrial relations; (8) experience of industrial work; (9) twinning programme; (10) community service programme; (11) curriculum-based industrial visits; and (12) educational entrepreneurship.

\subsection{Domain analysis and element (fourth round)}

Based on the interviews of the third round Delphi technique, all the panel experts $(n=11)$ agreed that only twelve main domains contribute to the construction of elements. In brief, the analysis technique schedule for the second round was used only for the approval of levels from panel experts. Further analysis of the study was combined with the two levels for the purpose of measuring each level. Based on the findings, the researchers found that a high level of interest not necessarily leads to high levels of approval. This can be seen in the level of interest for the domain of enterprise in the third round of study: Mean $=4.81$, CTT $=1.00$; while the level of agreement has the results of mean $=4.72$, and CTT $=1.00$. In the third round, there are two domains that have a level of interest and the highest approval level: governance and training providers $(\mathrm{Mean}=5.00, \mathrm{CTT}=.00)$. In the second round, there are three domains that have the level of interest with the lowest level of acceptance; they are delivery, assessment and industry work experience $($ mean $=4.36, \mathrm{CTT}=1.00)$. In the fourth round of study, there was consensus 
among the panel experts that three domains have levels of interest with the highest approval levels: governance, training providers and industry relationships (mean $=5.00, \mathrm{CTT}=.00)$. The following domains have the lowest interest level: industry work experience, twinning programmes, community service and industry tours based curriculum (Mean $=4.54$, CTT = 1.00). The domain with the lowest approval level is curriculum-based industry tour (Mean $=4.45$, CTT $=1.00)$. In this study, the panel experts had given consensus on all the twelve main domains. The experts also agreed that those domains will contribute to the construction of elements for integration training programmes of PTSI and PTC. Table 1.4 shows the level of interest of PTSI and integration programme of PTC for the automotive industry $(n=11)$.

\section{DISCUSSION}

Based on the findings and support from the experts, the study reveals that the twelve domains and elements can improve behavioural competencies and workable skills of coaches in the automotive industry. According to Buntat (2004), the employability skills are also known by other terms such as soft skills, behavioural skills, core competencies, core skills and people skills. These findings demonstrate that the employability skills should be a core skill that can be used in many occupations. Based on this study, the employability skills are not necessarily confined to a job or industry alone. The employability skills are needed in all areas and levels of employment and industrial sectors (Rasul et al., 2009a; Rasul \& Abd Rauf, 2010). This finding is also supported by Awang et al. (2006), Rasul (2009b); most of the employability skills needed in the workforce are more important than the actual ability to perform certain tasks. In this study, the survey conducted revealed the twelve important domains: (1) governance; (2) framework of qualifications; (3) standard of competence; (4) supplier of skill standards; (5) delivery; (6); assessment; (7) industrial relations; (8) experience of industrial work; (9) twinning programme; (10) community service programme; (11) curriculum-based industrial visits; and (12) educational entrepreneurship. These twelve domains can contribute most to improve behavioural competencies and employability skills that are more oriented towards workability requirements of the automotive industry.

However, to operate an effective TVET training system in the country, federal government financial contributions are needed not only for PTSIs and PTCs, but the state government involvement is also needed. The nation now requires 6 million skilled workers to ensure that Malaysia could achieve the developed nation status. Consequently, the educational institutions and industrial sector should work together in developing a curriculum in line with the 11th Malaysia Plan so that Malaysia can become a developed country by the year 2020. The curriculum should be reviewed and reformed in line with the changes to the country's automotive green technology so that the institutions can produce a workforce equipped with skills and high workability. The TVET curriculum training system should be renewed, in addition to meeting the requirements of the current job market. Holistic courses and programmes should be designed so that graduates can acquire workable skills required by the automotive sector. The findings of this study can help the younger generation to realise their potential in the coming years; PTSIs will benefit from the results of this study in producing a highly skilled workforce for the automotive industry. Therefore, the curriculum is a key element in the educational process; its scope is very broad, and it involves everyone engaged in the TVET training system, in one way or another.

Vol. 10, No.1| June 2018| ISSN 2229-8932 Journal of Technical Education and Training (JTET) | 87 


\section{CONCLUSION}

In summary, the study found twelve domains that contribute to the formation of behavioural competencies and workable skills of coaches. These are the twelve domains: (1) governance; (2) qualifications framework; (3) standard of competence; (4) supplier of skill standards; (5) delivery; (6); (7) industrial relations; (8) experience of industrial work; (9) twinning programme; (10) community service programme; (11) curriculum-based industrial visits; and (12) educational entrepreneurship. The operator or regulator of the TVET system should work more closely with PTSIs and PTCs to determine the direction of the training system. If the government is committed to achieving the annual target of producing 300 thousand skilled workers in various sectors, the domains and the specified elements should be taken into account in the implementation of the TVET training in PTSIs and PTCs.

\section{Acknowledgment}

We would like to record our appreciation for the award of U226 - RSGS (Research Supporting Grant Scheme), ORICC, Universiti Tun Hussein Onn Malaysia (UTHM).

\section{References}

Ahmad Nordin, A.F. (2009). Cabaran Dalam Pendidikan Latihan Teknikal dan Kerjaya (CTET) Bagi Menyokong Kerjaya Belia-Belia Dalam Membuat Keputusan, Seminar Kebangsaan Pendidikan Teknik Dan Vokasional Kali Ke-3 9 - 10 Disember 2009, Universiti Teknologi Malaysia., Skudai, Johor.

Ahmad, A. (2012). Effectiveness of learning transfer in national dual training system (NDTS). Penerbit Universiti Tun Hussein Onn Malaysia.

Awang, A.H., Hamzah, A., Uli, J., Ahmad, A. \& Ismail, R. (2008). Kemahiran Bolehkerja: Keseimbangan antara Tuntutan Majikan dan Penguasaan Pelatih. IJMS. UUM. 14(1) 212-244 (2006) citation at http://www./ijms.uum.edu.my.

Balnaves, M. \& Caputi, P. (2001). Introduction to Quantitative Research Methods : An Investigative Approach. London: SAGE Publications Inc.

Buntat, Y. (2004). Integrasi kemahiran employability dalam program pendidikan vokasional pertanian dan industri di Malaysia, Doctoral thesis: Universiti Teknologi Malaysia, Malaysia.

Buntat, Y. et. al (2008), Cabaran Politeknik Sultan Ahmad Shah (Polisas) Membangunkan Modal Insan Sejajar Dengan Keperluan Sektor Industri. Fakulti Pendidikan. Universiti Teknologi Malaysia: Skudai, Johor

Callan, V. J. (2002). A study of VET student and teacher attitudes to generic skills. A progress report. National VET Training Research Conference, Brisbane, 10 Julai

Chua, Y. P. (2006). Kaedah Penyelidikan. Malaysia: McGraw-Hill Sdn.Bhd.

Cummings, R. (1998), 'How we should access and report students generic attributes?' In Teaching and Learning in changing times: supervision and assesment. Eds B Black \& N Stanley proccedings of the 7th annual Teaching Leraning Forum, University of Western Australia, University of Western Australia, Perth, pp 85-90.

Department Skills Development. (2012). Laporan Tahunan. Kuala Lumpur.

Emat, Y. (2005). Pendidikan Teknik dan Vokasional di Malaysia. Petaling Jaya: IBS Buku Sdn. Bhd.

Esa, A. (2006). Peranan kokurikulum dalam pembangunan kemahiran generik. Univesiti Tun Hussien Onn Malaysia (UTHM). Thesis PhD.

Fong, C.O. (2005). Ucapan Perasmian Dialog Bersama CEO Syarikat Bagi Pelaksanaan Sistem Latihan Dual Nasional. Kuala Lumpur.

Vol. 10, No.1 $\quad$ June 2018| ISSN 2229-8932 Journal of Technical Education and Training (JTET) | 88 
Ismail, N.H. (2007). Penilaian Program Latihan Industri Pelatih-pelatih Politeknik Sultan Salahuddin Abdul Aziz Shah: Satu Kajian Kes Di Negeri Selangor. Fakulti Pendidikan. Universiti Kebangsaan Malaysia: Tesis Sarjana

ILO. (2003). Learning and Training for Work in the Knowledge Society: The constituents view, Report IV (2), International Labour Conference $91^{\text {st }}$. Session. Geneva, ILO.

Jab, A.T. (2007). Pembangunan Kurikulum Teknikal dan Vokasional. Bahagian Kurikulum Teknikal dan Vokasional, Jabatan Pendidikan Teknikal, Kementerian Pelatihan Malaysia (KPM): Bahagian Latihan dan Kemajuan Staf Jabatan Pendidikan Teknikal.

Lankard, B.A. (1994). Employers' expectations of vocational education. Columbus, OH: The National Centre for Research in Vocational Education, The Ohio State University.

Loose, G., Spottel, G. and Md Sahir, Y. (2008) Re-Engineering Dual Training The Malaysian Experience. Peter Lang. hlm 75-78. Deusche Gesellschart fur Tecnische Zusammenarbeit (GTZ) GmbH dan German Malaysia Institute (GMI).

Marican, S. (2005). Kaedah Pengkajian Sains Sosial. Selangor: Pearson, Malaysia Sdn.Bhd.

Meseran, H., Konting M.M., Aziz S.A., Wahab, H., Chan, K.F., Saiful dan Ramadzan H (2007). Pelaksanaan Latihan Industri di Universiti Putra Malaysia. Persidangan Pengajaran dan Pembelajaran di Peringkat Pengajian Tinggi: Kualiti Peningkatan Kualiti Modal.

Mighat, A.D. (2012). Penilaian Indikator dan Model Kelestarian Mata Pelatihan Vokasional (MPV) Sekolah Menengah Harian. Thesis PhD: Universiti Kebangsaan Malaysia. (UKM).

Ministry of Higher Education (2006a). Laporan Jawatankuasa Mengkaji, Menyemak dan Membuat Perakuan Tentang Perkembangan dan Hala Tuju Pendidikan Tinggi Malaysia. Jabatan Pengurusan Institusi Pengajian Tinggi, Pusat Penerbitan Universiti Teknologi MARA.

Md Ali, R., Yusof, N. \& Matzin (2008). Pelatih Politeknik Kurang di Beri Pendedahan Kepada Pembaikan, Penyelenggaraan dan Pelaksanaan Sesuatu Kerja Semasa Menjalani Latihan Industri. Politeknik Balik Pulau, Pulau Pinang.

Othman, A. (2003). The Role of The National Vocational Training Council in The Management of Vocational Training in Malaysia. A Critical Evaluation. Penerbit UTHM.

Pang, C.L. (2008a). The Integration of National Occupational Skills Standard-based Training System and The National Dual Training System in Malaysia: Journal of National Dual Training System Implementation in Malaysia, pp. 1-22. Ministry of Human Resources, Malaysia.

Pang, C.L. (2008b). A Historical Account of Skills Training in Malaysia. In Gerd, Loose, Georg Spottl and Yusof Md Sahir. Re-Engineering Dual Training The Malaysian Experience. Germany: Peter Lang. pp164-175.

Peck, R. \& Devor, J. L, (2012). Statistics: The Exploration and Analysis of Data. Seventh Edition. United State: Richard Stratton

Pillai, S. S. \& Yusuf, M. (2005). The Student Industrial Training. Kuala Lumpur: University of Malaya.

Rahim, N. A., Sidin H. Z. (2009). Kepentingan dan keperluan dalam bidang-bidang Kejuruteraan berasaskan latihan industri. Politeknik Sultan Abdul HalimMu'adzam Shah.

Rashidi, R. (2008). Framework for effective collaboration between public training institutions and industries in context of National Dual Training System environment in Malaysia. Journal of National Dual Training

System Implementation in Malaysia. pp.170-181. Ministry of Human Resources. Malaysia.

Rasul, M.S., Ismail M.Y., Ismail, N., Rajuddin, R. \& Abdul Rauf, R.A. (2009a). Aspek Kemahiran 'Employbility' yang dikehendaki Majikan Industri Pembuatan Masa Kini. Jurnal Pendidikan Malaysia. 34(2): pp.67-79.

Rasul, M.S.. Ismail, M.Y., Ismail, N., Rajuddin, R. \& Abdul Rauf R.A. (2009b). Peranan Institusi latihan kemahiran latihan kemahiran Pendidikan Teknikal Dalam Pemupukan Kemahiran "Employbility". Jurnal Teknologi, 50 (E) Jun 2009 : hlm 113-127.

Rasul, M.S. \& Abdul Rauf, R.A. (2010). Membangun Alat Ukur, Tahap Kemahiran Kebolehdapatan Kerja: Selangor, Universiti Putra Malaysia.

Sulaiman, M. (2010). Competencies Required By Industry Coaches To Perform New Tasks in Implementation of the National Dual Training System in Malaysia. Universiti Tun Hussien Onn Malaysia: Tesis Doktor Falsafah.

Sulaiman, M., Mohd Osman, M.H, Mohd Raffi, M.L. (2008). Kompetensi Keushawanan Di Antara Pelatih Yang Mendapat Pendedahan Formal Di Dalam Bidang Keusahawanan Dengan Pelatih Yang Tidak

Vol. 10, No.1 $\quad$ June 2018| ISSN 2229-8932 Journal of Technical Education and Training (JTET) | 89 
Mendapat Pendedahan. Persidangan Pembangunan Pelatih Peringkat Kebangsaan, Universiti Teknologi Malaysia., Skudai, Johor.

Tomiran, K. (2008). The Participation of SME's of Manufacturing Sector in The National Dual Training System (NDTS): Journal of National Dual Training System Implementation in Malaysia, pp. 212-237. Ministry of Human Resources, Malaysia.

Vogt, W. P. (2007). Quantitative Research Methods for Professionals. Boston: Pearson.

Wan Ahmad, W.S, (2004) To Inculcate Training Culture Amongst Malaysian industry through National Dual Training System (NDTS). Department of Skill Development. pp 2-15. 